\title{
Applied Linguistic-Tú and Usted Spanish Personal Subject Pronouns
}

\author{
Joel Laffita Rivera \\ Faculty of Applied Communication (FAC), Multimedia University (MMU), Cyberjaya, Malaysia \\ Email: joel.laffita@mmu.edu.my
}

How to cite this paper: Rivera, J. L. (2019). Applied Linguistic-Tú and Usted Spanish Personal Subject Pronouns. Open Journal of Modern Linguistics, 9, 12-24. https://doi.org/10.4236/ojml.2019.91002

Received: April 4, 2018

Accepted: January 28, 2019

Published: January 31, 2019

Copyright $\odot 2019$ by author(s) and Scientific Research Publishing Inc. This work is licensed under the Creative Commons Attribution International License (CC BY 4.0).

http://creativecommons.org/licenses/by/4.0/

\begin{abstract}
While the simple phonetics of Spanish language makes it easier to learn and speak irrespective of its grammar complexity, acquiring a good command of this language requires a serious and disciplined study of its grammar. The use of null and overt pronouns and their different grammar related forms in Spanish elevates the level of complexity when it comes to second language acquisition (SLA). In this regard, the teaching and learning of Spanish grammar still remains a subject of interest among linguists. Thereby, the article aimed to provide a guideline through which English language native speakers would gain an insight about language traits, associated with two pronouns and how they should be used in the speaking and writing context of Spanish language communication.
\end{abstract}

\section{Keywords}

Socio-Cultural, Syntax, Orthography, Grammar Patterns, Pragmatic and Linguistic, Teaching, Learning

\section{Introduction}

Communication is instigated to express human experiences and traits. It is the channel through which an individual can communicate his thoughts. The most common approach used by an individual for communicating is through speaking or writing. These skills require a good understanding of language to be used, particularly its grammar (Ortega, 1990) ${ }^{1}$. Unlike English, Spanish is an inflected language. The verbs are potentially marked for tense, aspect, mood, person, and number (resulting in some fifty conjugated forms per verb). The nouns form a two-gender system and are marked for number. Pronouns can be inflected for

${ }^{1}$ Ortega, Olivares J. Gramática, pragmática y enseñanzas de lenguas. Actas del I Congreso de ASELE, Granada. (1990). 
person, number, and gender, including a residual neuter (San José, 2010) ${ }^{2}$. The grammar of Spanish language possesses a rich, wide, and a variety of words, if compared to other languages. There are the words that are classified according to the use of orthographical accent or tilde "monosyllables words-pronoun tú". There are words that require others to get a concrete meaning "Pronouns tú and usted plus pronouns adjacent"; "pronouns tú and usted plus verb conjugation". There are words that can be omitted from the content of a sentence, already bequeathing its meaning to the following words "tú and usted". There are words that denote the use of what is known as Hispanic concept of proper etiquette "tú-informal/usted-formal", and from the point of view of translations from Spanish to English "tú and usted" are the English equivalent of "you" in most of the Spanish-speaking countries, excluding those where "vos" is the equivalent of "you". There are no additional efforts required for learning and speaking a language without studying its grammar; nevertheless, a serious and disciplined study of it would give an individual the advantage to organize the language (Bertuccelli, 1993) ${ }^{3}$. When it comes to acquiring the way, an individual should address the receiver "you-tú and usted" in Spanish language. Knowing about language traits related to these two pronouns will provide that person a better comprehension of this Spanish language grammar theme.

\section{Socio-Cultural Input}

Two of the peculiarities that distinguish the use of these two Spanish personal subject pronouns are the informal and the formal way, in which the two pronouns are treated in Spanish language communication. This has been the major consideration of English language native speakers when it comes to applying the use of tú and usted in Spanish language. A study of address patterns of Spanish personal subject pronouns Tú and Usted shows that L2 learners face difficulties in the interpretation of Spanish address forms (Gosselin, 2014) ${ }^{4}$. For many years, this Spanish language subject has been also the major concern of Spanish teachers in terms of teaching these pronouns to these kinds of learners. Nevertheless, knowing the ways with which these two pronouns should be used in Spanish language communication is not the most difficult task as many suggest. Generally, usted is used in reference to strangers, elders and social superiors while tú is used with friends, children and lower classes, although there is variation among individual speakers (Smith, 2013) ${ }^{5}$. From this cited statement, insight reveals the influence of socio-culture elements in the usage of these personal subject pronouns in Spanish language communication, which is nothing else than Spanish language socio-culture phenomenon. It is deemed that the subject personal pronoun tú is applicable for those treated as close relatives or friends. In other

${ }^{2}$ San José, Miguel Ángel (2010), A Reference Grammar of Spanish.

${ }^{3}$ Bertuccelli, M. Qué es la pragmática. Barcelona: Paidós, (1993).

${ }^{4}$ Gosselin, Karen Marie, 2014. A study of address patterns: Spanish informal and formal forms Tú and Usted.

${ }^{5}$ Smith, L 2013 The Acquisition of Tú and Usted by English Speakers. 
words, it is a genuine expression of familiarity and trusts. On the other hand, the subject personal pronoun usted is simply the way to treat others with respect. It is believed that the highlighted discussion would be beneficial in supporting the perception about the real scenario and situation.

Nowadays, the use of pronoun tú has come to be more practical among Spanish native speakers than the pronoun usted. This phenomenon is being imitated not just for English learner's speakers, but for many others non-native Spanish speakers. Therefore, it might be one of the causes for which number of English language native speakers frequently make an error when applying the address forms for usted which involve the use of different grammar shapes in Spanish.

\section{Syntax Input}

Although Spanish is a much more heavily inflected language than English; when it comes to semantic the word order of the Spanish into sentences is similar to its English equivalent: Subject-Verb-Object (SVO). However, in the context of Spanish personal subject pronouns tú and usted, studying Spanish grammar can be a complex task, taking into account that these two pronouns are not required when the grammar associated forms has an impact on the way they are applied in the writing and speaking context of Spanish language communication. For instances, salutations; address forms; advertises, signpost:

¿Cómo estás? (tû)/ ¿Cómo está, señor? (usted) Translated as How are you, Sr? ¿How is it going? = ¿Qué tal estás? $($ tû)/ ¿Qué tal está? (usted).

¿Cómo te llamas? (tû) ¿Cómo se llama? (usted), Translated as What is your

name?

¿Do you have email? $={ }_{¿}$ Tienes email? $(t \hat{)}) /_{¿}$ Tiene email? $($ usted $)$.

Buy the boss perfume. = Compre el perfume boss. $(t \hat{u}) /$ Compra el perfume

boss. (usted).

Go straight $=$ Siga recto $($ usted $)$.

As can be seen from the above-examples; the grammar associated forms of the two pronouns are the elements that define the semantic structure and the indented meaning of the speaker. When many academics focus the use of tú and usted from the perspective of socio-culture (formallinformal) treatment the most, they somehow forget the significant of knowing and studying the grammar shapes of the Spanish personal subject pronouns tú and usted, which in fact should be the main focus to get mastering this Spanish language syntax topic.

\section{Orthography Input}

Monosyllables Words: Generally, the monosyllables words in Spanish are not written with accent (tilde or acento ortográfico) as it is known. However, this particular aspect of accentuation is used in many Spanish words to distinguish one from the others with similar spelling. Such are the cases of many words: el article and él personal pronoun, té noun and te pronoun, including the pronoun 
tú and $t u$ possessive adjective etc. The use of accent/tilde also plays an important role in terms of syllable pronunciation in Spanish. For instance, interrogative sentences: ¿Cómo te llamas? In this example, the voice goes up in the beginning and decent in te llamas.

\section{Grammar Patterns Input}

Adjectives, Pronouns Adjacent, and Prepositions: The presence of tú and usted is a subject of interest, specifically when considering its actualization in Spanish grammar as personal pronouns. These two words take different persons, when ascertaining the subject personal pronouns in Spanish language. The pronoun tú takes the second person, and the pronoun usted takes the third person (together with the pronouns él and ella or he/she in English (Table 1). Both pronouns tú and usted are singular in Spanish language. English equivalent of these Spanish pronouns is the personal pronoun "you" (Table 2). But, it requires specific knowledge, when applying these two pronouns with adjectives, prepositions, and pronouns adjacent due to their connotation in Spanish language.

In Spanish, the prepositions "a", “de", "por", "para”, "con", "sin”, “en” never precede the pronoun tú. In the first four cases, the pronoun tú is replaced by the pronoun $t i$ while the special construction of "contigo" is used in the last one. In contrast, all those prepositions can precede the pronoun usted.

Verbs in Present Indicative Tense: The present indicative or simple present in Spanish language has some similarities with its English counterpart when it has to agree with the verb. It goes the same way with "you". However, unlike English, in Spanish language; its equivalent tú and usted are far from one another. It means that these two Spanish pronouns have their own verbal pattern conjugation. It is no often a comprehensive point for English language native speakers, particularly when applying their correct verbal conjugations forms. The main reason is not just due to the conjugation itself, but also because of duality that some verbs have in Spanish language as well. In particular, English language native speakers find it difficult to comprehend the verbs ser and estar, which are pronounced as to be in the English language. The verbal conjugation

Table 1. Examples of possessive pronouns and adjectives.

\begin{tabular}{ccc}
\hline Subject Pronouns & Possessive Adjectives & Possessive Pronouns \\
\hline tú (you) & tu (your) & tuyo/tuya/tuyos/tuyas (yours) \\
usted (you) & su (your) & suyo/suya/suyos/suyas (yours) \\
\hline
\end{tabular}

Table 2. Examples of direct, indirect and reflexive pronouns.

\begin{tabular}{cccc}
\hline Subject Pronouns & Direct Object Pronouns & Indirect Object Pronouns & Reflexive Pronouns \\
\hline tú (you) & te (you) & te (you & te (you \\
usted (you) & lo/la/le (you) & le (you) & se (you) \\
\hline
\end{tabular}


as well as the duality emerged in Spanish has always been one of the complex grammar tasks to overcome the difficulty of English language native speakers. In this regard, the appropriate examination of the spelling that distinguishes the verbal conjugations of tú and usted in relation to the verb cited can resolve particularly the verbal conjugation of the subject personal pronouns in Spanish.

(You are.) Tú eres./ Usted es./ Tú estás./ Usted está.

Even though, all four conjugations mean "You are" in English. It is quite important to observe the spelling of these verbs in present indicative tense within Spanish language. The intention of explaining this point is because of the verb "estar" identified in present indicative that require specific attention to focus on the letter " $s$ ", making the difference between the verbal conjugation of tú and usted in Spanish. However, this observation might not deem to be complex particularly in practice. Following verb conjugated forms of many regular and irregular verbs in Spanish language are shown below:

(You have.) Tú tienes./ Usted tiene.

(You know.) Tú conoces./Usted conoce.

(You know.) Tú sabes./ Usted sabe.

(You can.) Tú puedes./ Usted puede.

(You study.) Tú estudias./Usted estudia.

When it comes to apply verbal conjugations of many regular and irregular verbs for tú and usted; one of the major aspects is to actualize precisely the letter " $s$ ". Such peculiar details can be seen in a number of regular and irregular verbs in present indicative tense in Spanish. It is important to know that tú and usted can be omitted in the content of sentence Do you want...? ¿Quieres...?/ ¿Quiere...?, particularly in spoken Spanish. Unlike English language, the writing of interrogative sentences in Spanish requires the use of two question marks if they are direct interrogative sentences $(i \ldots$ ? ); one in the beginning of the sentence and the other in the end. The interrogation marks are not required when the sentences are not direct sentences. The grammar structure for making questions in Spanish does not require auxiliary verbs like "do" as it does in English.

Verbs in Present Perfect Compound Tense: Quite similar to its English counterpart, present perfect compound tense in Spanish requires an auxiliary verb. Its grammar construction in Spanish is made up by using verb "haber" as auxiliary verb, in which the English equivalent is "to have".

\section{(You have.) Tú has./ Usted ha.}

In addition, the past participle of Spanish verbs must be used to complete its grammar structure. It is made up of three different classes of verbs that exist in Spanish language. The first group of Spanish verbs ends in " $a r$ ", the second ends in " $e r$ " and the third ends in "ir". The past participle for the Spanish verbs end- 
ing in "ar" is "ado", for "er" is " $i d o$ ", and for " ir" is also " $i d o$ ".

To study = Estudiar/ To read = Leer/ To live = Vivir

You have studied. = Tú has estudiado./ Usted ha estudiado.

You have eaten. = Tú has comido./Usted ha comido.

It is important to inquire and apply present perfect compound tense in Spanish language communication even though it is not used in many Latin America Spanish-speaking countries than in Spain. The past participle of Spanish verbs will remain unchangeable. In other words, once it is known, the only thing to change is the Spanish auxiliary verb "haber" according to the tense, in which it is used.

Verbs in Simple Present Progressive Tense: The present progressive tense in Spanish is made up by using auxiliary verb, which is similar to English counterpart. The verb in Spanish has two forms "ser" and "estar", and the only one that must be used as auxiliary verb to make up this tense in Spanish is "estar".

(You are.) Tú estás./ Usted está.

In addition, the ing of Spanish verbs must be used to complete its grammar structure. It is made up of three different classes of verbs that exist in Spanish language. By substituting the verbs ending " $a r$ ", " $e r$ ", " $i r$ " of the Spanish verbs in infinite forms and replacing them with the ending "ando", "iendo", "iendo". However, the Spanish ing requires specific intention except for the infinite Spanish verbs ending in vowels, in which Spanish ing is "yendo". In the context of past participle of Spanish verbs, the Spanish ing will remain unchangeable. In other words, once it is known, the only thing to change is the Spanish auxiliary verb "estar" based on the tense in which it is used.

$$
\begin{aligned}
& \text { You are dancing. = Bailar. Tú estás bailando./ Usted está bailando. } \\
& \text { You are doing. = Hacer. Tú estás haciendo./Usted está haciendo. } \\
& \text { You are reading. Leer. Tú estás leyendo./Usted está leyendo. }
\end{aligned}
$$

\section{Pragmatic and Linguistic Input}

"Pragmatics is a subfield of linguistics and semiotics that emphasize the ways, in which context contributes to meaning. Pragmatics encompasses speech act theory, conversational implicature, talk in interaction and other approaches to language behavior in philosophy, sociology, linguistics, and anthropology. Unlike semantics, pragmatics studies how the transmission of meaning depends on both structural and linguistic knowledge (e.g., grammar, lexicon, etc.) of the speaker and listener. In the context of utterance, any pre-existing knowledge, inferred intent of speaker, and other factors are involved. In this respect, pragmatics explains how language users are able to overcome ambiguity, since meaning relies on the manner, place, time etc. of an utterance. The ability to understand 
another speaker's intended meaning is called pragmatic" (García \& Otheguy, 1977) $)^{6}$. Pragmatic will give a clear insight about those linguistic terminologies that require visible sings, sounds, environment etc. to apply the particular language, for instance, the questions, Are you tired? Are you mad?, are not particularly asked if the signs are already suggestive. By considering the significance and conjunction of the two in "applied syntax"; an example could be the translation of those English questions to Spanish.

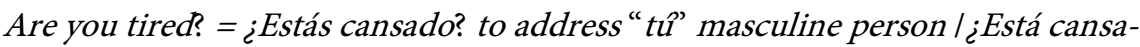
do? to address "usted" masculine person /¿Estás cansada? to address "tư" feminine person/¿Está cansada? to address "usted” feminine person.

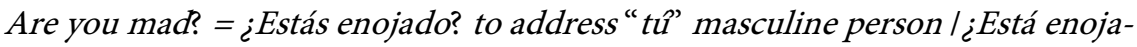
do? to address "usted" masculine person /¿Estás enojada? to address "tü" feminine person/¿Está enojada? to address "usted” feminine person.

As it can be observed from those examples, by right it will require more knowledge of Spanish syntax to comprehend those addressed forms and many others for tú and usted than the impact that pragmatic could has on them. Thus, it is necessary to study carefully the grammar associated form for tú and usted.

\section{Objective of the Study}

The core intention of this study has been to provide a guideline through which English language native speakers can get an insight about language traits associated with two pronouns and their significant usage in the speaking and writing context of Spanish language communication. Based on the fact that non-native speakers faced a significant difficulty regarding the usage of these Spanish personal subject pronouns; the study has reviewed inductive teaching and learning methods as a suitable medium to disseminate this knowledge to the Spanish learners. The inductive approach has been used to analyze the level of Spanish language proficiency in these learners regarding the use of these pronouns; therefore, it is recommendable as teaching approach in the development of language skills among non-native speakers according to the results of its application.

\section{Methodology}

\section{Rationale for selected methodology}

The mindset of English native language speakers is difficult to understand about Spanish grammar as the nature of grammatical functions is complex. The reason for such is mainly pointing to the influence of native language in the subconscious of these learners, which is so powerful not to be influenced, especially when it comes to adult students. The Spanish grammar topics cited ranges

\footnotetext{
"Dialectal Variation in leísmo: A Semantic Approach", in Fashold, Ralph W.; Shuy, Roger W., Studies in Language Variation: Semantics, Syntax, Phonology, Pragmatics, Social Situations, Ethnographic Approaches.
} 
from Spanish level A1-A2 according to what is prescribed by the Common European Framework of Reference for Language Learning, Teaching, Assignment (CEFR) (Consejo de Europa, 2001) ${ }^{7}$. Marco Común Europeo de Referencia para las Lenguas: aprendizaje, enseñanza, evaluación. In order to develop an avid interest among learners of Spanish language, it is necessary to enable students to understand the relevance of what they are learning and help them to apply it to various contexts. There are many teaching and learning methodologies that address this arena; such as deductive learning. However, it has been found to be most effective to use inductive teaching and learning methods to aid students in the development of their language skills. Such methods are inclusive of inquiry learning, project-based learning, discovery learning, case based teaching, just-in-time teaching and problem-based learning, and levy a greater responsibility on the students to acquire knowledge. Rather than initiating the learning process by discussing general language principles and then moving on to their practical applications, such inductive teaching begins with specifics in the form of experimental data for interpretation, case studies for analysis or a real-world problem that needs a solution. Through the examination of this specific data, students understand the significance of theoretical knowledge that they need to analyze this data accordingly. This is in stark contrast to the traditional teaching methodology that utilized lecture-based deductive learning. Therefore, this study has conducted an exploration of inductive teaching and learning approaches to enable students and to accomplish their Spanish language development in relation to the effective usage of tú and usted. A set of exercises will be provided to these students to help ascertain the level of their language proficiency regarding the applications of these pronouns.

\section{Teaching and Learning Guidance}

Firstly, it is important to make it clear for the English native language speakers that learning a new language will require a profound interest on their part, which is the key to accomplishing the language tasks given successfully. Letting them know that in terms of studying the grammar of Spanish language, it is necessary to remember that the Spanish language has its own grammar patterns. The students will therefore need to structure their learning approach in accordance with the program requirements. We thus initiate a set by step analysis of this discussion.

\section{Socio-Cultural Input}

A clear view about the positions is provided that tú and usted take in relation to verb conjugations before continuing to the next task. A note pertaining to the usage (formal and informal) of these pronouns in Spanish language is to be provided, which can be taken from this research paper. The students are asked to

${ }^{7}$ Consejo de Europa (2001). Marco Común Europeo de Referencia para las Lenguas: aprendizaje, enseñanza, evaluación. 
You (singular) English personal pronoun.
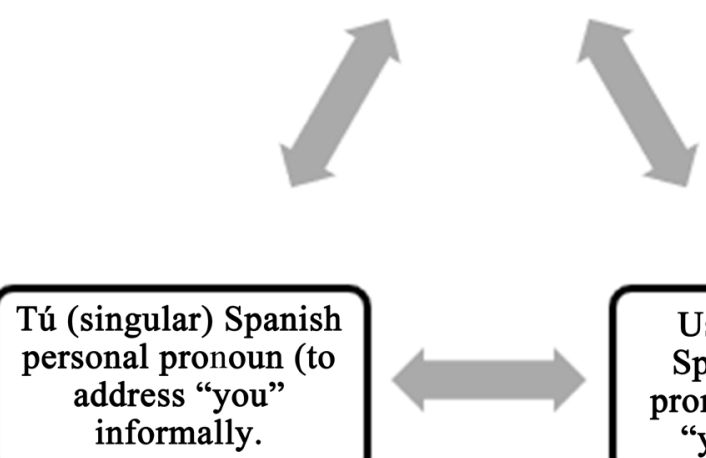

Figure 1. Personal subject pronouns.

focus on it for future roleplay dialogues (informal and a formal). It is necessary to remind the significant aspect in learning the grammar patterns for usted and that can be used as well to make statements about él/ella (he/she) in Spanish language (Figure 1).

Step 2: Tú and Usted-Verbs in Present Indicative Tense.

The study has used the examples of Spanish verbs in present indicative tense to create three kinds of sentences. Besides the conjugation of the verb to be "ser" in present indicative in Spanish, the letter " $\mathcal{~ " ~ m a k e s ~ t h e ~ d i f f e r e n c e ~ b e t w e e n ~ t h e ~}$ conjugated forms of tú and usted in this tense in a gran number of regular and irregular verbs in Spanish.

Ex. Tú quieres./Usted quiere./¿Quieres...?/¿Quiere...?/Tú no quieres.../Usted no quiere.

Step 3: Tú and Usted-Verbs in Present Perfect Compound Tense.

Additionally, the study has used the examples of Spanish verbs in present perfect compound tense to create three kinds of sentences. The letter "s" makes the difference between the conjugated forms of tú and usted in relation to the verb to have "haber", as well as about the use of the past participle of Spanish verbs "ado", "ido", "ido" to make this verb tense in Spanish.

Ex. Tú has comido./Usted ha comido./¿Has comido?/¿Ha comido?/Tú no has comido./Usted no ha comido.

Step 4: Verbs in Simple Present Progressive Tense.

The study has used the examples of Spanish verbs in present progressive tense to create three kinds of sentences. The verb "estar" can be used as auxiliary verb to make the progressive tense in Spanish, and the use of Spanish ing "ando", "iendo", "iendo", "yendo".

Ex. Tú estás trabajando./Usted está trabajando./¿Estás trabajando?/¿Está trabajando?/ Tú no estás trabajando./ Usted no está trabajando.

Exercise: Do the verb conjugations in the tenses shown in this paper research 
or from other sources. Ask students to fill-in the blanks by using tú or usted. Write a sentence for tú and/or usted and ask students to rewrite the sentence according to the correct conjugation.

Ex. compras./ compra.

Ans. Tú compras el pan./Usted compra el pan.

Tú vas. (Usted)

Exercise for repairing incomplete interrogative sentences for tú and usted. Practice their pronunciation.

Ex. ¿Cómo llamas?/¿Cómo llama?

Step 5: Adjectives and Prepositions and Pronouns Adjacent.

Exercise: Fill in the blanks with the possessive adjective, prepositions and pronouns. Create this kind of exercises by using phrases and sentences.

Ex. Este libro es ti. (porlpara).I usted es este regalo. (porl para).

Step 6: Graphical Accentuation.

Illustrate examples of Spanish monosyllabic words that require the use of orthographical accent to differentiate one from the other in Spanish language grammar (tú-tul más-mas/ té-tel mí-mil él-ell sí-si) etc.

Step 7: Tú and Usted-Pragmatic and Linguistic Input.

Organize a competition based on questions and answers for tú and usted. Example, provide information on request. Ask question to solve problems.

Ex. Me llamo Pablo. (I call myself Pablo.). ¿Cómo te llamas? (tû)/¿Cómo se llama? (usted) (How do you call yourself?).

\section{Results and Discussion}

This study made use of cognitive, meta-cognitive and affective components of learning to review the significance of teaching and learning approaches for Spanish language. It was discussed in studies that learning is comprised of these three components. These studies discussed that cognitive learning activities help students to process and critically analyze the provided information and contribute in the strengthening of their knowledge pertaining to that arena. Affective learning approaches are used by students to deal with the emotional responses that follow the learning process lastly, the meta-cognitive component of learning is involved in the exertion of control and responsibility over one's cognitive and affective processes in order to understand the information provided (Prince \& Felder, 2006) ${ }^{8}$. It may be seen that inductive learning and teaching approaches are an effective amalgamation of these three components of learning. Moreover, their utilization in disseminating information regarding Spanish pronoun usage would aid in the development of linguistic capabilities in Spanish language learners.

This study conducted close observations of personal pronouns tú and usted in

${ }^{8}$ Prince, M. J., \& Felder, R. M. Inductive teaching and learning methods: Definitions, comparisons, and research bases. Journal of engineering education, (2006) 95(2), 123-138. 
Spanish language communication. These observations were carrying out at Multimedia University (MMU), Malaysia among Spanish language students. It can be seen that English learner's speakers are prone to committing mistakes in correctly applying the grammar patterns of tú and usted in Spanish language. There are many factors that culminate in the restriction of these students to adequately learn and apply these personal pronouns in Spanish. These are inclusive of direct and inappropriate translations, insufficient knowledge about the proper usage of tú and usted-grammar patterns and lack of learning materials for Spanish grammar. The presence of null and overt pronouns and their own grammar patterns further complicates the learning process, because there is a necessity to display or omit these pronouns as per the contextual requirement. The presence of this null-pronoun variation has been noted in Mandarin Chinese as well (Jia \& Bayley, 2002) $)^{9}$. Additional factors include the influence of negative external sources in terms of learning choices and the design of specific teaching. Lack of proficiency may be attributed to ineffective learning methods that are employed by these students in the form of rote learning and memorization tactics. Such methods are extremely ineffective in helping students to gain a comprehensive understanding of how language is to be applied according to different contexts (Flores-Ferrán, 2004) ${ }^{10}$. In this case, the students were not able to correctly apply the pronouns in the appropriate situations. It suggests that a transformation is needed in the learning and teaching approaches that are currently employed by students and teachers respectively. Inductive teaching and learning approaches were discussed by studies to be an effective approach in the linguistic application of languages.

\section{Conclusion}

This study attempted to conduct an investigation pertaining to the efficacy of teaching and learning practices related to Spanish grammar with non-native speakers, particularly English native speakers. The grammar components selected to conduct and demonstrate the veracity of this research article are as follow: Subject personal pronouns Tú and Usted. This study pertained to the appropriate use of these pronouns in the Spanish language and contained an explicit explanation about the formal and informal usage of these Spanish personal pronouns. Additionally, this study intended to emphasize other linguistic elements associated with the usage of tú and usted and pointed out their significant role. In conclusion, the study has explained the influence of socio-cultural, orthography, pragmatic and linguistic and grammatical aspects that characterized the use of these Spanish personal subject pronouns in the speaking and writing context of Spanish language communication. This study also highlights the inductive learning and teaching approaches in enabling Spanish learners to devel-

${ }^{9}$ Jia, L., \& Bayley, R. Null pronoun variation in Mandarin Chinese. University of Pennsylvania Working Papers in Linguistics, (2002) 8(3), 9.

${ }^{10}$ Flores-Ferrán, N. Spanish subject personal pronoun use in New York City Puerto Ricans: Can we rest the case of English contact?. Language variation and change, (2004) 16(1), 49-73. 
op their language skills. Therefore, it is essential that repetitive studies should be conducted to gauge the efficacy of teaching and learning approaches in the acquisition of Spanish and the appropriate pronoun usage pertaining to this language.

\section{Conflicts of Interest}

The author declares no conflicts of interest regarding the publication of this paper.

\section{References}

Bertuccelli, M. (1993). Qué es la pragmática. Barcelona: Paidós.

Consejo de Europa (2001). Marco Común Europeo de Referencia para las Lenguas: aprendizaje, enseñanza, evaluación.

Flores-Ferrán, N. (2004). Spanish Subject Personal Pronoun Use in New York City Puerto Ricans: Can We Rest the Case of English Contact? Language Variation and Change, 16, 49-73. https://doi.org/10.1017/S0954394504161048

García, É., \& Otheguy, R. (1977). Dialectal Variation in leísmo: A Semantic Approach. In R. W. Fashold., \& R. W. Shuy (Eds.), Studies in Language Variation: Semantics, Syntax, Phonology, Pragmatics, Social Situations, Ethnographic Approaches (pp. 65-88). Washington DC: Georgetown University Press.

Gosselin, K. M. (2014). A Study of Address Patterns: Spanish Informal and Formal Forms Tú and Usted, L2 learners' Difficulties in the Interpretation of Spanish Address Forms. The University of Minnesota Digital Conservancy.

Jia, L., \& Bayley, R. (2002). Null Pronoun Variation in Mandarin Chinese. University of Pennsylvania Working Papers in Linguistics, 8, 9.

Ortega, O. J. (1990). Gramática, pragmática y enseñanzas de lenguas. Granada: Actas del I Congreso de ASELE.

Prince, M. J., \& Felder, R. M. (2006). Inductive Teaching and Learning Methods: Definitions, Comparisons, and Research Bases. Journal of Engineering Education, 95, 123-138. https://doi.org/10.1002/j.2168-9830.2006.tb00884.x

San José, M. Á. (2010). A Reference Grammar of Spanish. Cambridge: Cambridge University Press.

Smith, L. (2013). The Acquisition of Tú and Usted by English Speakers. 


\section{Additional References}

Alkubaidi, M. A. The Relationship between Saudi English Major University Students' Writing Performance and Their Learning Style and Strategy Use. English Language Teaching, (2014) 7(4), 83-95.

Alvar, Manuel. 1996. Manual de dialectología hispánica. Ariel. ISBN 978-84-344-8218-0.

Batchelor, R[onald] E[rnest]; San José, Miguel Ángel (2010), A Reference Grammar of Spanish, Cambridge University Press, ISBN 978-0-521-42961-0

Boekaerts, M. Self-regulated learning: Bridging the gap between metacognitive and metamotivation theories. Educational Psychologist, (1995) 30(4), 195-200.

Butt, John; Benjamin, Carmen (2011), A New Reference Grammar of Modern Spanish (5th ed.), Hodder Education, ISBN 978-1-4441-3769-9

Carvalho, A. M., Orozco, R., \& Shin, N. L. Subject pronoun expression in Spanish: A cross-dialectal perspective. Georgetown University Press. (2015)

DeBruyne, Jacques (1996), A Comprehensive Spanish Grammar, Wiley-Blackwell, ISBN 978-0-631-19087-5

Flores Ferrán, N. A bend in the road: Subject personal pronoun expression in Spanish after 30 years of sociolinguistic research. Language and Linguistics Compass, (2007) 1(6), 624-652.

García, Érica; Otheguy, Ricardo (1977), "Dialectal Variation in leísmo: A Semantic Approach", in Fashold, Ralph W.; Shuy, Roger W., Studies in Language Variation: Semantics, Syntax, Phonology, Pragmatics, Social Situations, Ethnographic Approaches, Georgetown University Press, pp. 65-88, ISBN 0-87840-209-8

Gómez Torrego, Leonardo. 2006. Hablar y escribir correctamente: Gramática normativa del español actual. Arco Libros. ISBN 978-84-7635-653-1.

Iran-Nejad, A. Active and dynamic self-regulation of learning processes. Review of Educational Research, (1990) 60(4), 573-602.

Pérez, Ángeles; Rafael Sala; and Manuel Santamarina. 1994. Cassell's Contemporary Spanish. MacMillan. ISBN 978-0-02-595915-6.

Roque Mateos, Ricardo. 2017. A Good Spanish Book!: Basic Spanish Course for Foreigners. University Academic Editions. ISBN 978-15-4269-745-3.

Shin, N. L. Grammatical complexification in Spanish in New York: 3sg pronoun expression and verbal ambiguity. Language Variation and Change, (2014) 26(3), 303-330.

Vermunt, J. D., \& Verloop, N. Congruence and friction between learning and teaching. Learning and instruction, (1999) 9(3), 257-280.

Zimmerman, B. J., \& Bandura, A. Impact of self-regulatory influences on writing course attainment. American Educational Research Journal, (1994) 31(4), 845-862. 